ISSN 1392-3196 / e-ISSN 2335-8947

Zemdirbyste-Agriculture, vol. 100, No. 3 (2013), p. 235-242

DOI $10.13080 / \mathrm{z}-\mathrm{a} .2013 .100 .030$

\title{
Biodegradation activity in the soil contaminated with oil products
}

\author{
Dalia AMBRAZAITIENE $\dot{E}^{1,2}$, Audronė ŽUKAUSKAITE் ${ }^{1}$, Viktorija JAKUBAUSKAITÉ ${ }^{1}$, \\ Raimonda REIKAITÉ ${ }^{1}$, Monika ZUBRICKAITE் ${ }^{1}$, Danute KARČAUSKIENË $\dot{E}^{1,2}$ \\ ${ }^{1}$ Klaipèda University \\ H. Manto 84, Klaipėda, Lithuania \\ E-mail: dalia.ambrazaitiene@ku.lt \\ ${ }^{2}$ Vėžaičiai Branch, Lithuanian Research Centre for Agriculture and Forestry \\ Gargždų 29, Vėžaičiai, Klaipėda distr., Lithuania
}

\begin{abstract}
The current study is aimed to determine how sewage sludge may impact the biodegradation activity of soil contaminated with oil products and what groups of microorganisms are most active in it. Bathihypogleyi-Dystric Albeluvisol ( $A B d$-gld-w) with a texture of sandy loam was selected for laboratory tests. The soil was contaminated with heavy fuel oil 15 and $30 \mathrm{~g} \mathrm{~kg}^{-1}$, supplemented with sewage sludge to create three backgrounds: 1) without sludge, 2) $5 \%\left(50 \mathrm{~g} \mathrm{~kg}^{-1}\right)$ and 3) $10 \%\left(100 \mathrm{~g} \mathrm{~kg}^{-1}\right)$ of sludge for air-dried soil. The trend was determined that when treating soil contaminated with heavy fuel oil the highest treatment efficiency was achieved by supplementing the soil with $10 \%$ of activated sewage sludge. Microorganisms which take part in the process of biodegradation of heavy fuel oil demonstrated different levels of activity during the investigation period. Hydrocarbon-oxidizing bacteria and micromycetes are the most important groups of microorganisms involved in the degradation of heavy fuel oil products in the soil. The initial concentration of heavy fuel oil in the soil had no statistically significant differences for all analyzed groups of microorganisms, although the number of bacteria and micromycetes, capable of oxidizing oil products, was statistically significantly influenced by the degradation time. The increasing concentration of sewage sludge statistically significantly affected the total number of bacteria and actinobacteria.
\end{abstract}

Key words: bacteria, concentrations, heavy fuel oil, hydrocarbon-oxidizing bacteria, micromycetes, sewage sludge.

\section{Introduction}

Oil product spills are possible in all stages of oil extraction, transportation or usage. After being emitted into the environment, these products strongly affect the ecosystems: $\mathrm{pH}$ and aeration level of soil change most often, biota is exposed to toxicity and its biological activity is weakened, soil degradation probability increases (Shabir et al., 2008; Beškoski et al., 2011). Some of the volatile oil product components evaporate (Laškova et al., 2007; Paulauskienė et al., 2009), others contaminate the soil (Vasarevičius et al., 2005). In order to restore the biological properties of soil, the biological treatment is preferred.

Soils contain a very large number of microorganisms, which can include a number of hydrocarbonutilizing bacteria and fungi (Namkoong et al., 2002). In addition, cyanobacteria and algae found in the soil have been found to be able to degrade hydrocarbons. The rate of degradation of organic compounds will be dependent on the structure of the compound. The simpler aliphatic and monocyclic aromatics are readily degradable, but the more complex structures are not readily degraded and may persist for some time. Some compounds can be absorbed by clays and are thus rendered invulnerable

to degradation. To overcome this problem surfactants have been added to contaminated soils to improve the availability of hydrocarbons. The rate of degradation depends on the microbial population, the type and level of contamination (Boldu-Prenafeta et al., 2004). Another way of increasing the biodegradation efficiency can be improving the aeration; the addition of biogenic elements (phosphorus, nitrogen, potassium) has also been proposed (Liužinas, Jankevičius, 2003; Si-Zhong et al., 2009). Moreover, it is also being offered to introduce biopreparations or other active substances, rich in microorganisms. Usage of complex biocultures artificially made of several microorganism species for hydrocarbon degradation which possess well-know oil oxidation properties, or naturally formed microorganism combinations (Shabir et al., 2008) was known a long while ago. Adapted autochthonous microorganisms are considered as the most prospective and efficient measure. According to Gestel et al. (2003) it is possible to use biowaste (vegetables, fruits, waste from pruning and other gardening operations) for composting, during which the soil is cleaned of oil products. Meanwhile, other authors (Chander et al., 1997) indicate that the diesel fuel would 
be biodegraded more intensely if the diesel-contaminated soil were supplemented with additional organic matter, e.g., sewage sludge, since this organic matter is abundant in substances beneficial for microorganisms. This is probably due to the fact that the additional sludge microflora is introduced, which can break down organic acids, capture atmospheric nitrogen, etc. Comparison of the ability of different bacteria to dispose of oil products suggests that cocci can "soak up" the substrate with the whole surface of the cell while depleting less energy for being more active (Maier, Soberon-Chavez, 2000). It is estimated that there are about 70 genera of bacteria that are capable of breaking down hydrocarbons (Repečkiené et al., 2002; Prince, 2005). Biodegradation activity of micromycetes promotes the decomposition of heavy oil fractions, depending on their systematic affinity, the number of origins, the ability to synthesize various enzymes and release organic acids and other metabolites into environment (Ellis et al., 2001).

There is no waste in a natural environment, and biodegradation takes place continuously; any organic substance can better supply the entire complex of microorganisms with metabolised nutritional elements and result in final products of oxidation of organic compounds: carbon dioxide and water. In this way, the sewage sludge would be a particularly suitable complex of organic substances that can serve to reduce the oil pollution in the soil (Mishra et al., 2001). Even though this topic has been under a scientific spotlight for a long time, the usage possibilities of the sewage sludge are limited, because of possible contamination with heavy metals or presence of pathogenic microorganisms (Insam et al., 1996).

Therefore, the aim of this work was to determine how sewage sludge can influence the biodegradation activity of soil contaminated with oil products, as well as to determine what groups of microorganisms influence these processes most. It is known that the efficiency of this process depends on the number of microorganisms present in the soil and their ability to adapt, specificity of their functioning, nutritional substances suitable for growth, composition of pollutants, and physicochemical properties of soil (Iwamoto, Nasu, 2001; Vasudevan, Rajaram, 2001; Boldu-Prenafeta et al., 2004). It was determined earlier that a small amount of metals in the sewage sludge only speeds up the treatment. The treatment efficacy of diesel-contaminated soil using manganese (Mn) salts reached $90 \%$ within 120 days, using salts of copper $(\mathrm{Cu})-86 \%$, while control sample achieved only $75 \%$. The treatment efficacy of soil contaminated with heavy fuel oil using $\mathrm{Mn}$ and $\mathrm{Cu}$ salts almost doubled during the same period: 63,59 and $34 \%$, respectively (Žukauskaitè et al., 2008).

\section{Materials and methods}

The study was conducted in vitro (under laboratory conditions) in Klaipeda University during $05112009-14042010$, using pots, $5 \mathrm{~kg}$ of dry soil was placed per pot; microbiological and heavy fuel oil test was made in triplicate. Bathihypogleyi-Dystric Albeluvisol (Abd-gld-w) with a texture of sandy loam from Klaipèda University Botanical Garden was used in the tests. Chemical soil characteristics were: $\mathrm{pH}-5.5$ (ISO 10390:2005. Soil quality. Determination of $\mathrm{pH}$ ),
$\mathrm{P}_{2} \mathrm{O}_{5}-380 \mathrm{mg} \mathrm{kg}{ }^{-1}, \mathrm{~K}_{2} \mathrm{O}-307 \mathrm{mg} \mathrm{kg}^{-1}$ (LVP D-07: 2012 (Egner-Riem-Doming (A-L) method), organic carbon $1.25 \%$ (ISO 10694:1995. Soil quality. Determination of organic and total carbon after dry combustion (elementary analysis)), total nitrogen - 0.14\% (ISO 11261:1995. Soil quality. Determination of total nitrogen - Modified Kjeldahl method. This standard has been reviewed and then confirmed in 2010). At the beginning of the experiment the soil was artificially polluted with heavy fuel oil: 15 and $30 \mathrm{~g} \mathrm{~kg}^{-1}$. Then sewage sludge was added to the soil to create three test backgrounds: 1) without sludge, 2) $5 \%\left(50 \mathrm{~g} \mathrm{~kg}^{-1}\right)$ and 3$) 10 \%\left(100 \mathrm{~g} \mathrm{~kg}^{-1}\right)$ sewage sludge for dried soil. The sewage sludge from $\mathrm{AB}$ "Klaipedos vanduo" Dumpiai wastewater treatment plant was used. The following composition of metals and biogenic substances was determined for sewage sludge: $\mathrm{Cr}-$ $42.19 \mathrm{mg} \mathrm{kg}^{-1}, \mathrm{Cu}-197.89 \mathrm{mg} \mathrm{kg}{ }^{-1}, \mathrm{Ni}-14.68 \mathrm{mg} \mathrm{kg}^{-1}$, $\mathrm{Zn}-569.16 \mathrm{mg} \mathrm{kg}^{-1}, \mathrm{~Pb}-24.71 \mathrm{mg} \mathrm{kg}^{-1}, \mathrm{Cd}-1.28 \mathrm{mg} \mathrm{kg}$ ${ }^{1}$ (ISO 11047:2004. Soil quality. Cadmium, chromium, cobalt, copper, lead, manganese, nickel and zinc in soils by extraction of the royal water. Flame and electrothermal atomic absorption spectrometric methods), $\mathrm{Hg}-0.60 \mathrm{mg}$ $\mathrm{kg}^{-1}$ (ISO EN 1483:2007. Mercury. Method using atomic absorption spectrometry), total $\mathrm{N}-488892.2 \mathrm{mg} \mathrm{kg}^{-1}$ (ISO EN 13342:2002. Characterization of sludges. Nitrogen by the Kjeldahl total), total $\mathrm{P}-24068.8 \mathrm{mg} \mathrm{kg}^{-1}$ (LAND 782006. Determination of total phosphorus in the sludge), $\mathrm{pH}-6.38$ (ISO 10390:2005. Soil quality. Determination of $\mathrm{pH})$. Organic matter content in the sludge was $71.07 \%$ (ISO EN 12879:2002), dry matter - 23.18\% (ISO EN 12880:2002. Characterization of sludges. Dry residue and water content). According to contamination with heavy metals it was sewage sludge of the $1^{\text {st }}$ category, and it was taken from the treatment plant after centrifuge dewatering (LAND 20-2005. Requirements of using sewage sludge for fertilizing). In addition, the oil-purified soil is generally used for rehabilitation of affected areas (roadside, landfill covering, etc.) and not used for agricultural purposes. During the experiment the soil was aerated once a week by mixing it in pots; soil moisture of approximately $20 \%$ was maintained during the study. At the beginning of the study the content of all pots was enriched with ammonium nitrate $\left(\mathrm{NH}_{4} \mathrm{NO}_{3}\right)-0.6 \mathrm{~g} \mathrm{~kg}^{-1}$, and potassium chloride $(\mathrm{KCl})-0.06 \mathrm{~g} \mathrm{~kg}^{-1}$ of soil. Microbiological analysis was conducted 12, 22 and 66 days after the beginning of the experiment. During microbiological analysis the following four groups of microorganisms were distinguished: total number of colony forming units (CFU) of bacteria, actinobacteria, hydrocarbon-oxidizing bacteria (HOB) and micromycetes per 1 gram of absolutely dry soil. Dilution methods (Zviagincev, 1991) were used to estimate the number of microorganisms; the growth medium (peptone - $10 \mathrm{~g}, \mathrm{Na}_{2} \mathrm{HPO}_{4}-2 \mathrm{~g}, \mathrm{MgSO}_{4}-0.5 \mathrm{~g}, \mathrm{FeCl}_{3}-0.005 \mathrm{~g}$, $\mathrm{CaCO}_{3}-0.1 \mathrm{~g}, \mathrm{KH}_{2} \mathrm{PO}_{4}-0.1 \mathrm{~g}$, agar $-20 \%, 1000 \mathrm{ml}$ of distilled water) was used for total number of bacteria; acid mash agar ( $3.5^{\circ}$ according to Balling) was used to separate soil micromycetes; growth medium was used to detect the HOB: the composition of this medium $\mathrm{NH}_{4} \mathrm{PO}_{3}$ $-1 \mathrm{~g}, \mathrm{KH}_{2} \mathrm{PO}_{4}-1 \mathrm{~g}, \mathrm{~K}_{2} \mathrm{HPO}_{4}-1 \mathrm{~g}, \mathrm{MgSO}_{4}-1 \mathrm{~g}, \mathrm{CaCl}_{2}^{3}$ $\times 6 \mathrm{H}_{2} \mathrm{O}$ (saturated solution) - small drop, agar $-20 \%$, hydrocarbon (liquid) 1-2 ml. The concentrations of oil products in soil were tested during 150 days' period with a gas chromatograph "Shimadzu GC-2010" (Japan), with a non-polar column and a flame ionization detector (FID) according to ISO16703-2004 standard. 
Statistical analysis was made using Statgraphics plus software. The influence of factors on microorganisms' growth, the biodegradation process rate and oil products' concentrations was evaluated using analysis of variance $(A N O V A)$. The significance levels of the results are given at the $P<0.05$.

\section{Results and discussion}

Changes in heavy fuel oil concentrations in the soil enriched with sewage sludge were analyzed for 150 days. This is the average time taken by biological soil treatment process under Lithuanian climatic conditions, during which the concentration of oil products $\left(5 \mathrm{~g} \mathrm{~kg}^{-1}\right)$, permitted for soils of other than agricultural purposes, is practically achieved. In our study, the concentration close to that level was achieved in the treatment of soil contaminated with heavy fuel oil $15 \mathrm{~g} \mathrm{~kg}^{-1}$ and $10 \%$ sewage sludge. The data presented in Table suggest that within the first 30 days the largest amounts of heavy fuel oil $(7.3 \%)$ were removed from the soil, which did not contain sewage sludge. In the soil which contained 5\% sewage sludge, heavy fuel oil concentration decreased by $0.2-0.3 \mathrm{~g} \mathrm{~kg}^{-1}$ and degradation efficiency was $0.7-$ $2.0 \%$; in the samples with $10 \%$ of sewage sludge it was $2.7-3.7 \%$, respectively. And only later, after 60 days the degradation in many test cases was similar: $11.3-14 \%$. However, the largest part of it was removed from the soil which contained the highest concentrations of heavy fuel oil and sewage sludge.

Table. Changes in heavy fuel oil concentrations and degradation efficiency in the soil

\begin{tabular}{|c|c|c|c|c|c|c|}
\hline \multicolumn{2}{|c|}{ Soil contamination } & \multicolumn{5}{|c|}{ Degradation period, days } \\
\hline \multirow{2}{*}{$\begin{array}{c}\text { Heavy fuel } \\
\text { oil } \\
\mathrm{g} \mathrm{kg}^{-1}\end{array}$} & \multirow{2}{*}{$\begin{array}{c}\text { Sewage } \\
\text { sludge } \\
\%\end{array}$} & \multicolumn{5}{|c|}{$\frac{\text { Heavy fuel oil concentrations } \mathrm{g} \mathrm{kg}^{-1} \text { of dry soil }}{\text { Degraded oil } \%}$} \\
\hline & & 30 & 60 & 90 & 120 & 150 \\
\hline \multirow{6}{*}{15} & \multirow{2}{*}{0} & $13.9 \pm 2.3$ & $12.9 \pm 3.0$ & $\underline{12.4 \pm 1.6}$ & $10.5 \pm 1.9$ & $9.6 \pm 1.1$ \\
\hline & & 7.3 & 14.0 & 17.3 & 30.0 & 36.0 \\
\hline & \multirow{2}{*}{5} & $\underline{14.7 \pm 1.3}$ & $\underline{13.3 \pm 1.9}$ & $\underline{12.1 \pm 1.3}$ & $\underline{11.4 \pm 3.2}$ & $9.4 \pm 1.2$ \\
\hline & & 2.0 & 11.3 & 19.3 & 24.0 & 37.3 \\
\hline & \multirow{2}{*}{10} & $\underline{14.6 \pm 1.5}$ & $\underline{13.3 \pm 1.7}$ & $\underline{12.0 \pm 2.2}$ & $10.4 \pm 2.4$ & $7.6 \pm 1.9$ \\
\hline & & 2.7 & 11.3 & 20.0 & 30.7 & 49.3 \\
\hline \multirow{6}{*}{30} & \multirow[b]{2}{*}{0} & $27.8 \pm 4.7$ & $26.2 \pm 2.7$ & $24.8 \pm 1.9$ & $\underline{17.0 \pm 2.3}$ & $20.7 \pm 2.4$ \\
\hline & & 7.3 & 12.7 & 17.3 & 43.3 & 31.0 \\
\hline & \multirow[b]{2}{*}{5} & $29.8 \pm 4.0$ & $26.0 \pm 3.5$ & $23.5 \pm 2.6$ & $21.1 \pm 3.1$ & $\underline{19.5 \pm 2.6}$ \\
\hline & & 0.7 & 13.3 & 21.7 & 29.7 & 35.0 \\
\hline & \multirow{2}{*}{10} & $28.9 \pm 3.8$ & $\underline{24.1 \pm 4.4}$ & $20.8 \pm 3.1$ & $20.2 \pm 2.5$ & $\underline{17.2 \pm 2.1}$ \\
\hline & & 3.7 & 19.7 & 30.7 & 32.7 & 42.7 \\
\hline
\end{tabular}

It can be argued that this situation occurred because the larger number of sewage sludge particles during the initial period reduced the evaporation of volatile oil compounds from soil due to the absorption into the sludge particles (Namkoong et al., 2002), and later between 30-60 days, intensity and nature of processes capable of removing oil from the soil equalized and the efficiency of heavy fuel oil removal remained similar till the end of experiment. Still, at the end of the study $11-13 \%$ higher degradation efficiency was achieved in the samples with $10 \%$ of sewage sludge. These results suggest that oil degradation under natural conditions is relatively lengthy and depends on the level of pollution. One of the objectives was achieved and it was found that sewage sludge can speed up this process, although not essentially. Microbiological tests were conducted in order to assess the role of soil microorganisms in the process of removal of oil products from polluted soils. The main attention was dedicated to the groups of microorganisms, which, as is expected, play the greatest role in decomposition of organic substances of different origins in the soil. Microorganisms which are able to assimilate a xenobiotic compound obtain priority to develop in a polluted environment (Dai et al., 2004).

The total number of bacteria was determined; microorganisms of this group participate primarily in the decomposition of readily degradable organic compounds in soil (Gallego et al., 2001). Actinobacteria constitute a group of microorganisms, which are one of the most sensitive groups in response to the contamination of soils, as it is indicated in literature (Repečkienè et al.,
2002). Micromycetes have an enzyme system, capable of decomposing heavy hydrocarbons which emerge during breakdown of oil products (Zhdanova et al., 2004). We determined the oil products oxidizing microorganisms to evaluate in which stage of decomposition of oil products the biological processes are the most intensive. When analyzing the dynamics of bacteria in the soil polluted with heavy fuel oil, it was determined that their number at the beginning of the experiment weakly depended on the heavy fuel oil concentration in the soil and constituted 46.2-53.4 $\times 10^{6} \mathrm{CFU} \mathrm{g}^{-1}$ of absolutely dry soil (Fig. 1 $\mathrm{a}$ and $\mathrm{b}$ ). During the study, the number of bacteria exhibited a similar decreasing trend, i.e. their number in both pollution test cases decreased twice over the next 10 days of the experiment, and reached $29-43 \%$ of the initial number at the end of the experiment.

Increasing of the number of bacteria in the soil, in which the sewage sludge was added was found during the first 12 days after beginning of study, especially after addition of sewage sludge $10 \%$ of dry soil weight (Fig. 1). The number of bacteria at $5 \%$ of sewage sludge addition in soil was very similar and reached 54.9-56.9 $\times 10^{6} \mathrm{CFU} \mathrm{g}^{-1}$ of absolutely dry soil, irrespective of the concentration of oil products. While addition of $10 \%$ of the sludge increased this number almost twice - up to $76.4-82.3 \times 10^{6} \mathrm{CFU} \mathrm{g}^{-1}$ of absolutely dry soil. This is understandable because part of the bacterial microflora entered the soil with sewage sludge, enriched the soil with organic matter, which is readily decomposable by bacteria. We assume that the latter statement is confirmed by the fact that already after 10 days the number of bacteria 
decreased again twice and at the end of the experiment remained close to the initial only where $10 \%$ of sewage sludge was added. The concentration of oil products had no impact on the change of the number of bacteria in soil, even though indications related to biodegradation potential of aerobic and anaerobic bacteria are given in literature (Salminen et al., 2004).

The obtained results were validated by the multi-factor analysis of variance with significance level at $p<0.05$. Results of analysis of variance show

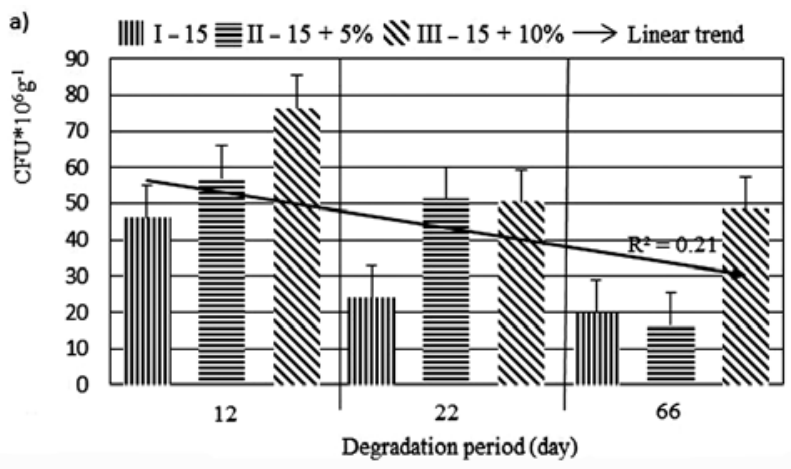

I - without sludge, II - 5\% and III - 10\% for dried soil that the influence of sludge on the number of bacteria was strongly statistically significant $(F=28.79)$; study duration also had a strong statistical significance $(F=$ $54.36)$, but the concentration of oil product in the soil had no influence on this parameter $(F=0.02)$. Analysis of bacterial population dynamics in the soil polluted with oil product and sewage sludge revealed a linear overall declining trend of their number over time: $R^{2}=0.21$, at $15 \mathrm{~g} \mathrm{~kg}^{-1}$ and $R^{2}=0.23$, at $30 \mathrm{~g} \mathrm{~kg}^{-1}$ for soil polluted with heavy fuel oil (Fig. 1).

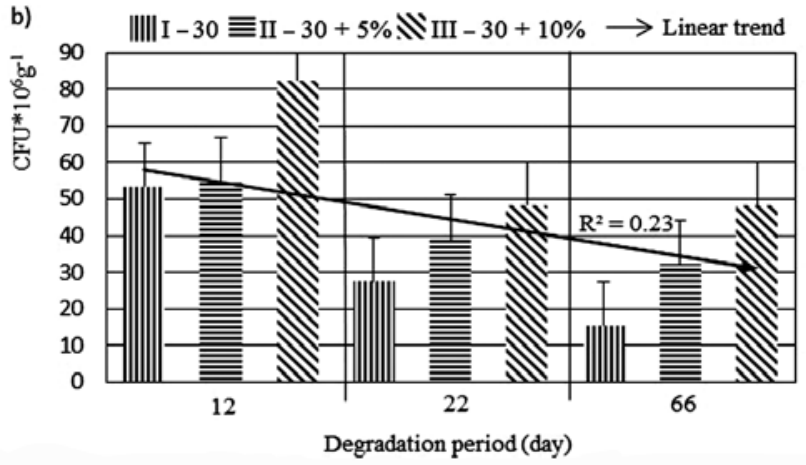

Figure 1. Bacterial population dynamics in the soil with different pollution levels: a) heavy fuel oil concentration 15 $\mathrm{g} \mathrm{kg}^{-1}$ of soil, b) heavy fuel oil concentration $30 \mathrm{~g} \mathrm{~kg}^{-1}$ of soil

The number of actinobacteria, as it can be seen in Figure 2, is considerably lower in the soil contaminated with oil product and sewage sludge, compared with the total number of bacteria; their number varies from 0.33 $\times 10^{6}$ to $1 \times 10^{6} \mathrm{CFU} \mathrm{g}^{-1}$ of absolutely dry soil. This taxonomic group is typical of microbocenoses of soil, but it could be seen even from the beginning of the study that it depends on the concentration of heavy fuel oil in soil, i.e. their number reduced $30 \%$ under higher pollution. Addition of sludge to the soil contaminated with $15 \%$ heavy fuel oil reduced the number of microorganisms of this group only during the first 12 days, but later their number was comparable to baseline, both with added sludge and without it. At the end of the experiment there were almost twice less of actinobacteria, compared with the beginning of the study. Heavy fuel oil concentration of $30 \mathrm{~g} \mathrm{~kg}^{-1}$ in soil, the number of actinobacteria remained stable throughout the investigation; however, a trend of

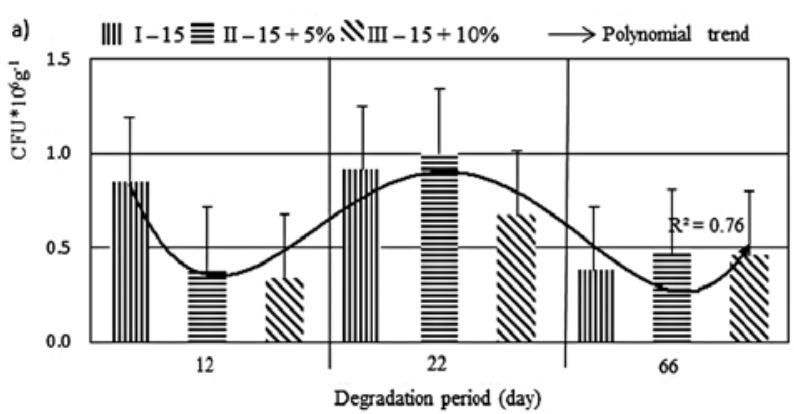

I - without sludge, II - 5\% and III - 10\% for dried soil decreasing was observed in the soil enriched with a larger amount of sludge. It was found that actinobacteria growth intensified just a decline in oil product concentration in the soil. These results are similar to those described by Repečkiene and co-authors (2002) where they stated that actinobacteria are sensitive to environmental pollution. After evaluation of influence of factors using analysis of variance, it was determined that the concentration of oil product $(p<0.05, F=0.56)$ and time elapsed from the beginning of the experiment $(p<0.05, F=1.79)$ did not affect the number of actinobacteria in the soil samples. The amount of sewage sludge in the soil was a statistically significant factor related to activity of actinobacteria ( $p<$ $0.05, F=5.17$ ). Changes in the number of actinobacteria during the experiment in the soil polluted by heavy fuel oil and enriched by sewage sludge can be described by a polynomial curve: $R^{2}=0.76$, at $15 \mathrm{~g} \mathrm{~kg}^{-1}$, and $R^{2}=0.62$, at $30 \mathrm{~g} \mathrm{~kg}^{-1}$ of soil contaminated with heavy fuel oil (Fig. 2).

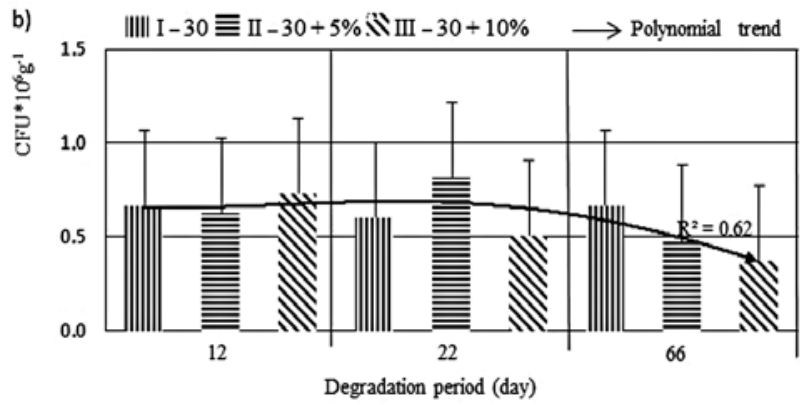

Figure 2. Actinobacterial population dynamics in the soil with different pollution levels: a) heavy fuel oil concentration $15 \mathrm{~g} \mathrm{~kg}^{-1}$ of soil, b) heavy fuel oil concentration $30 \mathrm{~g} \mathrm{~kg}^{-1}$ of soil 
Number of hydrocarbon-oxidizing bacteria (НOB) varied from $0.83 \times 10^{6}$ to $3.56 \times 10^{6} \mathrm{CFU} \mathrm{g}^{-1}$ of absolutely dry soil (Fig. 3). This group of microorganisms is the main destructor of oil products in contaminated soil (Dai et al., 2004). When analyzing changes of HOB in the soil polluted with heavy fuel oil only, it was found that at the beginning of the study the heavy fuel oil concentration did not determine the activity of these microorganisms essentially. Within 22 days after the beginning of the experiment, microorganisms of this group reached the maximum activity and their number increased threefold. At the end of microbiological examination, i.e. three months after the start of the experiment, the number of $\mathrm{HOB}$ decreased 1.7 times at the initial heavy fuel oil concentration in soil of $15 \mathrm{~g} \mathrm{~kg}^{-1}$, compared to the maximum number, but still remained 1.8 times higher than at the beginning of the experiment. This suggests that the biological degradation of heavy fuel oil is still continuing. Similar development trend of this group of microorganisms is indicated in the works of other authors: the average half-life for degradation of diesel fuel and heavy oils is in the order of 54 days with this type of system

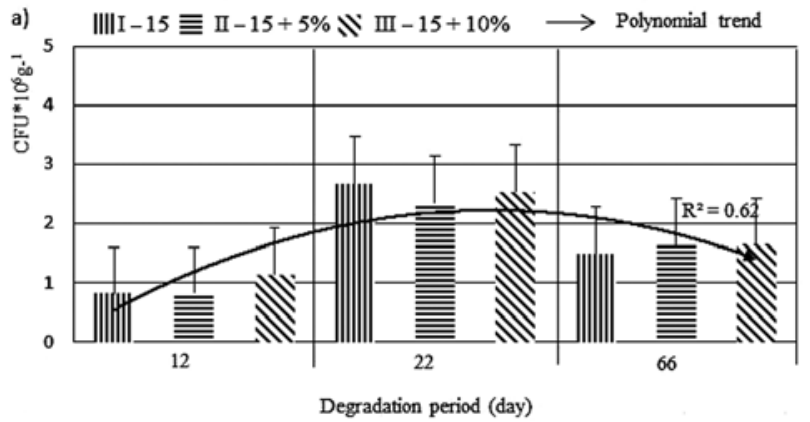

I - without sludge, II - 5\% and III - 10\% for dried soil
(Gallego et al., 2001). In the soil contaminated with higher heavy fuel oil concentration $\left(30 \mathrm{~g} \mathrm{~kg}^{-1}\right.$ of absolutely dry soil) the maximum number of HOB was also determined in 22 days after the beginning of the experiment, but at the end of the study it was close to the initial number. The variation of the number of microorganisms of this group under higher heavy fuel oil concentration in the soil was greater in all stages of investigation. Sewage sludge did not have any significant influence on the number of HOB at the beginning of the study. During the peak activity of this group of microorganisms, the sewage sludge in the soil reduced the number of bacteria in soils from 1.5 to 1.7 times at $30 \mathrm{~g} \mathrm{~kg}^{-1}$ of heavy fuel oil. Meanwhile, the changes of HOB number were not very obvious at a lower heavy fuel oil concentration in the soil. At the end of the experiment, sludge concentration of $5 \%$ in soil promoted the development of HOB both in the first and the second test backgrounds of pollution with heavy fuel oil, and increased their number almost twice compared to the baseline; however, at sludge concentration of $10 \%$ this trend remained only in the soil less contaminated with heavy fuel oil.

Figure 3. Dynamics of the number of hydrocarbon-oxidizing bacteria over time in the soil with different pollution levels: a) heavy fuel oil concentration $15 \mathrm{~g} \mathrm{~kg}^{-1}$ of soil, b) heavy fuel oil concentration $30 \mathrm{~g} \mathrm{~kg}^{-1}$ of soil

Analysis of data using analysis of variance showed the time elapsed since the beginning of the experiment is a statistically significant factor influencing the number of HOB $(p<0.05, F=50.58)$. Maximum number of HOB was observed after 22 days of experiment. Sewage sludge and concentration of oil product in the soil had no statistically significant influence on the abundance of this population, since $p>0.05$ was valid for both test backgrounds. Changes in the number of HOB during the experiment can be described by a polynomial curve, the weight direction of which is indicated by a factor $R^{2}=$ 0.62 at soil pollution with heavy fuel oil at $15 \mathrm{~g} \mathrm{~kg}^{-1}$ and $R^{2}=0.45$ at $30 \mathrm{~g} \mathrm{~kg}^{-1}$.

Analysis of micromycetes in polluted soil. After 12 days from the beginning of the experiment the number of micromycetes in the soil polluted with both levels contamination of heavy fuel oil was similar: 12.0-13.5 $\times$ $10^{3} \mathrm{CFU} \mathrm{g}^{-1}$ (Fig. 4). It increased 1.7-1.9 times within the next 10 days, and reached $42.2 \times 10^{3} \mathrm{CFU} \mathrm{g}^{-1}$ absolutely dry soil at the end of the experiment. The number of micromycetes was not influenced by the concentration

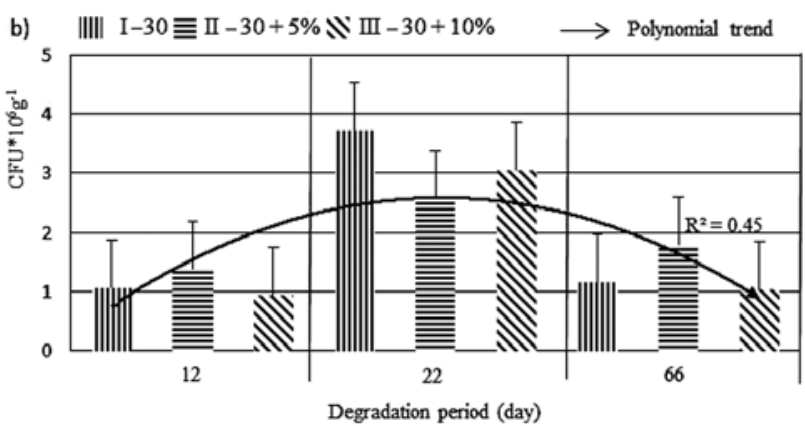

of heavy fuel oil. Addition of sewage sludge to soil increased the number of microorganisms of this group approximately 50 percentage units compared with the first 12-day and 22-day periods of the experiment. At the end of the experiment, this additive gave a greater increase in the abundance of populations of micromycetes at both concentrations of heavy fuel oil in the soil. The analysis of variance indicated that the time elapsed since the beginning of the experiment was the only statistically significant factor for growth of micromycetes $(p<0.05$, $F=119.14$ ), while soil pollution with heavy fuel oil and sewage sludge had no statistically significant influence on the growth of micromycetes. General dynamics of micromycetes number in the investigated soil is described by exponential, for which $R^{2}=0.85$ at soil pollution with heavy fuel oil of $15 \mathrm{~g} \mathrm{~kg}^{-1}$ and $R^{2}=0.69$, at $30 \mathrm{~g} \mathrm{~kg}^{-1}$.

In the absence of statistically validated evidence that the growth of the number of micromycetes could be related to decomposition of oil product, we are confident that microorganisms of this group could be important for decomposition of oil product. The increase in the 

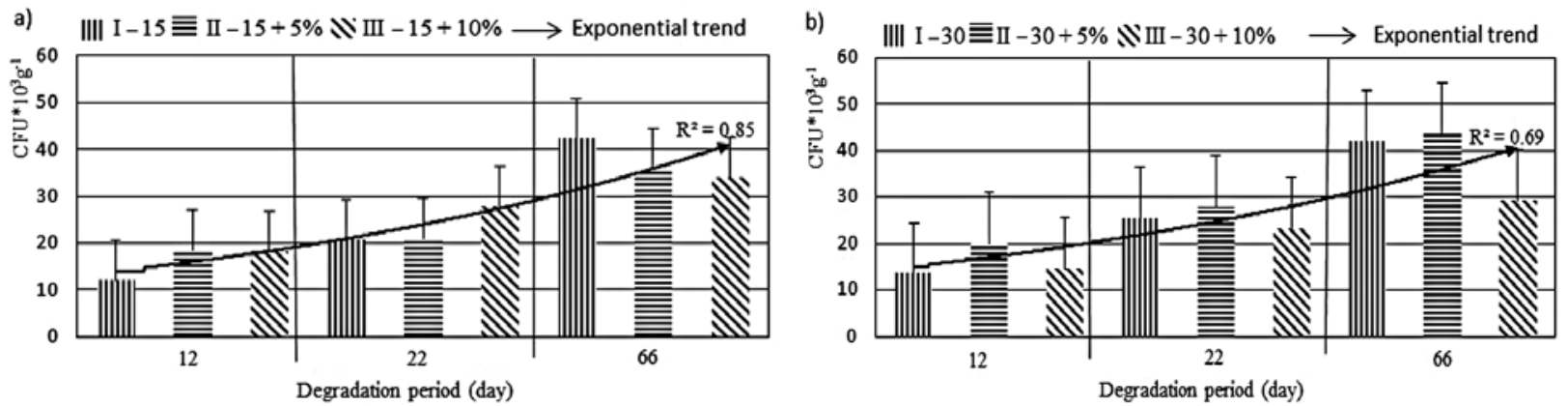

I - without sludge, II - 5\% and III - 10\% for dried soil

Figure 4. Dynamics of the number of micromycetes over time in the soil with different pollution levels: a) heavy fuel oil concentration $15 \mathrm{~g} \mathrm{~kg}^{-1}$ of soil, b) heavy fuel oil concentration $30 \mathrm{~g} \mathrm{~kg}^{-1}$ of soil

number of Penicillium genus observed at the end of the experiment could have implications in biodegradation of heavy fuel oil product since representatives of this genus can absorb up to $80 \%$ of oil products and oil components. The predominance of this genus among others (Penicillium, Aspergillus, Gliomastix, Cladosporium, Alternaria, Botrytis, Fusarium, Mucor) in the soil from filling stations polluted with oil products is also indicated in other works (D'Annibale et al., 2006). A high number of fungi of the mentioned genus prevailed in the soil, where the concentration of heavy fuel oil was $15 \mathrm{~g} \mathrm{~kg}^{-1}$ of dry soil; the number of representatives of genus Penicillium decreased after the oil concentration in the soil increased twice. Other authors consider this genus as a very numerous in a natural environment and therefore does not reflect the specificity of the substrate. Micromycetes may survive in harsh conditions for a very long time, while receiving minimal amounts of nutrients or using xenobiotic substrates which are not suitable for growth of other microorganisms (Zhdanova et al., 2004). Particularly this group of microorganisms together with bacteria are considered as the most important agents for biodegradation of oil hydrocarbons in soil (BolduPrenafeta et al., 2004).

\section{Conclusions}

1. The current study confirmed that during the treatment of soil polluted with heavy fuel oil (15 and 30 $\mathrm{g} \mathrm{kg}^{-1}$ ) the best trend towards degradation efficiency was achieved by adding $10 \%\left(100 \mathrm{~g} \mathrm{~kg}^{-1}\right)$ of sewage sludge into the soil. Degraded oil content during the investigation period increased from 11.7 to $13.3 \%$ depending on the soil pollution level. Therefore, sewage sludge could be suggested for use as a natural additive to promote the biological activity of soils.

2. Microorganisms involved in the biodegradation of heavy fuel oil demonstrated a different activity during the period of investigation: bacteria were the most active in early stage of the experiment; although the number of hydrocarbon-oxidizing bacteria (HOB) and actinobacteria significantly increased after 22 days since the beginning of the study; the number of all the groups decreased on day 66 of the experiment, but the number of micromycetes consistently increased until the end of the experiment. So the $\mathrm{HOB}$ and micromycetes are the most important groups of soil microorganisms involved in the different stages of heavy fuel oil degradation.

3. The initial concentration of heavy fuel oil in the soil had no statistically significant effect on the number of all tested groups of microorganisms; the both concentrations of sewage sludge statistically significantly affected only the total number of bacteria and actinobacteria.

\section{Acknowledgements}

This work was partly supported by the Lithuanian Science Council Student Research Fellowship Award (R. Reikaitè).

Received 18092012

Accepted 31052013

\section{References}

Beškoski V. P., Gojgic-Cvijovic G., Milic J., Ilic M., Miletic S., Šolevic T., Vrvic M. M. 2011. Ex situ bioremediation of a soil contaminated by mazut (heavy residual fuel oil) - a field experiment. Chemosphere, 83: 34-40 http://dx.doi.org/10.1016/j.chemosphere.2011.01.020

Boldu-Prenafeta F. X., Ballerstedt H., Gerritse J., Grotenhuis J. T. C. 2004. Bioremediation of BTEX hydrocarbons: effect of soil inoculation with the toluene-growing fungi Cladophialoporasp.StrainT1.Biodegradation, 15(1):59-65 http://dx.doi.org/10.1023/B:BIOD.0000009973.53531.96

Chander K., Brookes P. C., Harding S. A. 1997. Microbial biomass dynamics following addition of metal - enriched sewage sludge to a sandy loam. Soil Biology and Biochemistry, 27: 1409-1421

http://dx.doi.org/10.1016/0038-0717(95)00074-O

Dai J., Becquer T., Rouiller J. H., Reversat G., BernhardReversat F., Lavelle P. 2004. Influence of heavy metals on $\mathrm{C}$ and $\mathrm{N}$ mineralisation and microbial biomass in $\mathrm{Zn}-, \mathrm{Pb}-$, $\mathrm{Cu}$, and Cd-contaminated soils. Applied Soil Ecology, 25 (2): 99-109 http://dx.doi.org/10.1016/j.apsoil.2003.09.003

D’Annibale A., Rosetto F., Leonardi V., Federici F., Petruccioli M. 2006. Role of autochthonous filamentous fungi in bioremediation of a soil historically contaminated with aromatic hydrocarbons. Applied Environmental Microbiology, 72 (1): 28-36 http://dx.doi.org/10.1128/AEM.72.1.28-36.2006 
Ellis L. B. M., Hershberger C. D., Bryzan E. M., Wackett L. P. 2001. The university of Minnesota biocatalysis/ biodegradation database: emphasizing enzymes. Nucleic Acids Research, 29 (1): 340-343 http://dx.doi.org/10.1093/nar/29.1.340

Gallego J. L. R., Loredo J., Llamas J. F., Vazquez F., Sanchez J. 2001. Bioremediation of diesel contaminated soils: evaluation of potential in situ techniques by study of bacterial degradation. Biodegradation, 12: 325-335 http://dx.doi.org/10.1023/A:1014397732435

Gestel K. V., Mergaert J., Swings J., Coosemans J., Ryckeboer J. 2003. Bioremediation of diesel oil-contaminated soil by composting with biowaste. Environmental Pollution, 125: 361-368 http://dx.doi.org/10.1016/S0269-7491(03)00109-X

Insam H., Hutchinson T. C., Reber H. H. 1996. Effects of heavy metals stress on the metabolic quotient of the soil micro flora. Soil Biology and Biochemistry, 28: 691-694 http://dx.doi.org/10.1016/0038-0717(95)00182-4

Iwamoto T., Nasu M. 2001. Current bioremediation practice and perspective. Bioscience and Bioengineering, 92 (1): $1-8$

Laškova T., Zabukas V., Vaitiekūnas P. 2007. Influence of meteorological conditions on volatile organic compound spread in the atmospheric boundary layer. Journal of Environmental Engineering and Landscape Management, 15 (3): 135-143

Liužinas R., Jankevičius K. 2003. Microbiological processes in municipal sewage. Aplinkos tyrimai, inžinerija ir vadyba, 3 (25): 21-28 (in Lithuanian)

Maier R. M., Soberon-Chavez G. 2000. Pseudomonas aeruginosa rhamnolipids: biosynthesis and potential applications. Applied Microbiology and Biotechnology, 54: 625-633 http://dx.doi.org/10.1007/s002530000443

Mishra S., Jyot J., Kuhad R. C., Lal B. 2001. Evaluation of inoculum addition to stimulate in situ bioremediation of oily-sludge-contaminated soil. Applied Environmental Microbiology, 67: 1675-1681 http://dx.doi.org/10.1128/AEM.67.4.1675-1681.2001

Namkoong W., Hwang E. Y., Park J. Y. 2002. Bioremediation of diesel-contaminated soil with composting. Environmental Pollution, 119: 23-33 http://dx.doi.org/10.1016/S0269-7491(01)00328-1

Paulauskienė T., Zabukas V., Vaitiekūnas P. 2009. Investigation of volatile organic compound (VOC) emission in oil terminal storage tank parks. Journal of Environmental Engineering and Landscape Management, 17 (2): 81-89 http://dx.doi.org/10.3846/1648-6897.2009.17.81-88

Prince R. C. 2005. The microbiology of marine oil spill bioremediation. Ollivier B., Magot M. (eds). Microbiology. Washington, USA, $317 \mathrm{p}$.

Repečkienè J., Januška V., Paškevičius A., Lugauskas A. 2002. Amount and species diversity of microorganisms in fueloil-contaminated soil. Botanica Lithuanica, 4: 91-101 (in Lithuanian)

Salminen J. M., Tuomi P. M., Suortti A. M., Jørgensen K. S. 2004. Potential for aerobic and anaerobic biodegradation of petroleum hydrocarbons in boreal subsurface. Biodegradation, 15: 29-39 http://dx.doi.org/10.1023/B:BIOD.0000009954.21526.e8

Shabir G., Afzala M., Anwarb F., Tahseena R., Khalida M. Z. 2008. Biodegradation of kerosene in soil by a mixed bacterial culture under different nutrient conditions. International Biodeterioration and Biodegradation, 52 (2): 161-166 http://dx.doi.org/10.1016/j.ibiod.2007.06.003
Si-Zhong Y., Hui-Jun J., Zhi W., Rui-Xia H., Yan-Jun J., Xiu-Mei L., Shao-Peng Y. 2009. Bioremediation of oil spills in cold environments: a review. Pedosphere, 19 (3): 371-381 http://dx.doi.org/10.1016/S1002-0160(09)60128-4

Vasarevičius S., Greičiūtė K., Šiaulytė E. 2005. Investigation and evaluation of soil pollution with oil products in the most intensively used territories of Gaižiūnai military training ground. Journal of Environmental Engineering and Landscape Management, 13 (4): 160-167

Vasudevan N., Rajaram P. 2001. Bioremediation of oil sludgecontaminated soil. Environment International, 26: 409-411 http://dx.doi.org/10.1016/S0160-4120(01)00020-4

Zhdanova N. N., Tugay T., Dighton J., Zheltonozhsky V., McDermott P. 2004. Ionizing radiation attracts soil fungi. Mycological Research, 108 (9): 1089-1096 http://dx.doi.org/10.1017/S0953756204000966

Zviagincev D. G. 1991. Metodi pochvenoj mikrobiologii i biochimii. Moskva, 304 p. (in Russian)

Žukauskaitė A., Jakubauskaitè V., Belous O., Ambrazaitienė D., Stasiškienè Ž. 2008. Impact of heavy metals on the oil products biodegradation process. Waste Management and Research, 26: 500-507 http://dx.doi.org/10.1177/0734242X08089838 
ISSN 1392-3196 / e-ISSN 2335-8947

Zemdirbyste-Agriculture, vol. 100, No. 3 (2013), p. 235-242

DOI $10.13080 /$ z-a.2013.100.030

\title{
Naftos produktų biodegradacinis aktyvumas dirvožemyje
}

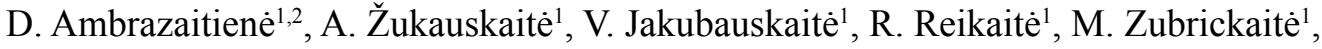 \\ D. Karčauskienè $\dot{1}^{1,2}$ \\ ${ }^{1}$ Klaipèdos universitetas \\ ${ }^{2}$ Lietuvos agrarinių ir miškų mokslų centro Vèžaičių filialas
}

\section{Santrauka}

Tyrimo tikslas - nustatyti, kaip nuotekų dumblas gali veikti naftos produktais užteršto dirvožemio biodegradacinị aktyvumą ir kokios mikroorganizmų grupės jame yra aktyviausios. Laboratoriniams tyrimams pasirinktas giliai glejjiškas nepasotintas balkšvažemis (JIn-g0), kurio granuliometrinė sudetis - smėlingas priemolis. Dirvožemis buvo užterštas 15 bei $30 \mathrm{~g} \mathrm{~kg}^{-1}$ mazuto ir i ji pridèta nuotekų dumblo, sukuriant tris fonus: 1) be dumblo, 2) $5 \%$ $\left(50 \mathrm{~g} \mathrm{~kg}^{-1}\right)$ ir 3) $10 \%\left(100 \mathrm{~g} \mathrm{~kg}^{-1}\right)$ orasausiam dirvožemiui. Nustatyta tendencija, kad valant mazutu užterštą dirvožemị, didžiausią degradacinị efektyvumą galima pasiekti, ị dirvožemị pridèjus $10 \%$ nuotekų dumblo. Tyrimo laikotarpiu mazuto biodegradacijoje dalyvaujantys mikroorganizmai buvo nevienodo aktyvumo. Naftą oksiduojančios bakterijos ir mikromicetai buvo svarbiausi dirvožemyje vykstant naftos produktų degradaciniams procesams. Pradinė mazuto koncentracija dirvožemyje visoms tirtoms mikroorganizmų grupėms esminès ịtakos neturejjo, tačiau naftos produktus oksiduojančių bakterijų ir mikromicetų kiekį esmingai lèmė degradacijos laikas. Didèjanti dumblo koncentracija turèjo esminès įtakos bendram bakterijų ir aktinomicetinių bakterijų kiekiui.

Reikšminiai žodžiai: bakterijos, koncentracijos, mazutas, mikromicetai, naftos produktus oksiduojančios bakterijos, nuotekų dumblas. 